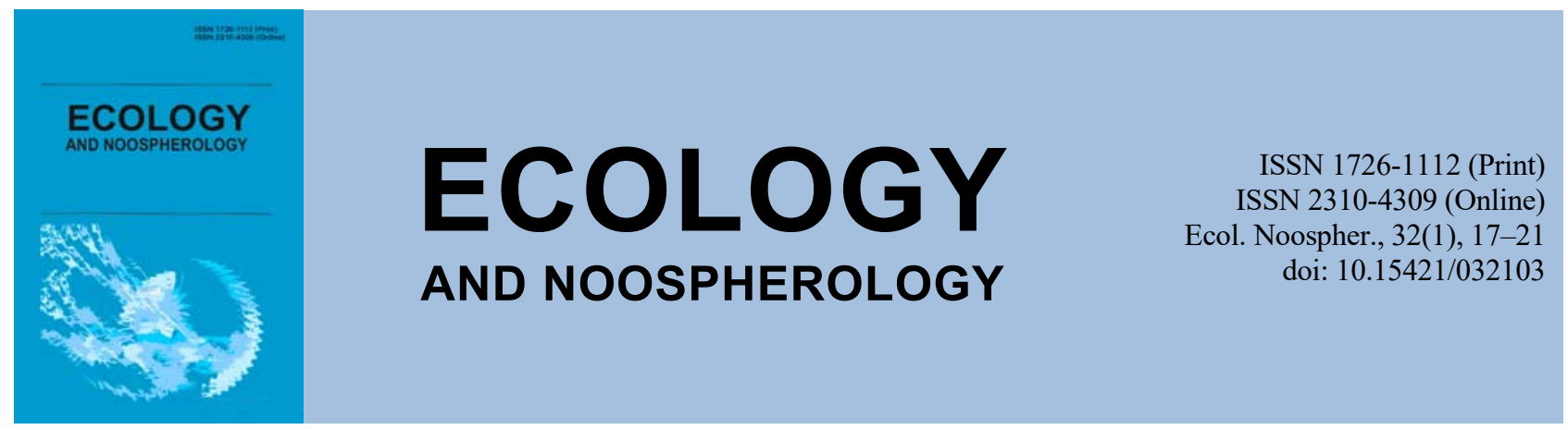

\title{
Influence of ultraviolet radiation on aquatic plants in conditions of low lighting
}

\author{
O. O. Shugurov, G. M. Oliynik
}

Oles Honchar Dnipro National University, Dnipro, Ukraine

Article info

Received 22.05.2021

Received in revised form

28.05.2021

Accepted 12.06.2021

Oles Honchar Dnipro

National University,

Gagarin Ave., 72, Dnipro,

49010, Ukraine.

Tel.: +38-066-509-44-99

E-mail: oshugurov@gmail.com
Shugurov, O. O., Oliynik, G. M. (2021). Influence of ultraviolet radiation on aquatic plants in conditions of low lighting. Ecology and Noospherology, 32(1), 17-21. doi:10.15421/032103

The effect of ultraviolet radiation (UV-r) on aquatic vegetation in conditions of general insufficient illumination was studied in laboratory conditions. In the studies such species of aquatic vegetation were used - submerged hornwort (Ceratophyllum demersum), thai fern (Microsorium pteropus), and globular cladophore (Aegagropila linnaei). The studies were carried out simultaneously in 3 aquariums, 3 liters each, with five iterations. For each of the experiments, the containers with water were covered with black paper on all sides, and 3 plants of each species were placed. Low-power LEDs were installed above the water surface of each aquarium. 2 white LEDs of the FYL-3014SRC brand (each with a power of $0.06 \mathrm{~W}$ at a luminous intensity of $600 \mathrm{mcd}$ ) were used for control experiments. In other versions of experiments with irradiation, we used -2 white and 2 UV-diodes (similar power), and 2 white diodes together with 6 UV-diodes. Every week during the experiment, the morphometric parameters (weight, leaf area, length) and color of vegetation were measured during a 30-day continuous exposure from the sources described above. At the end of the experiment, it was found that with a general low power of white illumination, the presence of additional UV-r can have a multidirectional effect on vegetation that lives at different levels of the water system. Thus, UV irradiation negatively affects rootless plants of the upper layers of aquatic systems (Ceratophyllum demersum), probably due to known disturbances in the their photosynthetic apparatus. UV-r led to a decrease in the mass and leaf area of such plants (by 80-90\%), a change in their color, disruption of their vital activity, the development of tissue decay processes and even death by the end of the experiment. On root plants (Microsorium pteropus) with arrow-shaped leaves pointing upwards, additional UV-r can support the light balance and to some extent compensate (by 10-15\%) the overall decline in the level of their development (by 60-75\%). Bottom vegetation (Aegagropila sauterii), living at a depth of up to $5 \mathrm{~m}$, is able to fully compensate for the lack of natural illumination by UV irradiation. UV-r penetrates the water column and after re-radiation on elements of aqueous solution penentrates to a considerable depth in the form of longer waves, and then used of plants with a general increase in the measured parameters by $5-20 \%$. This article concludes that the final effect on aquatic plants is formed by the depth of their habitat and the total intensity of light falling on the surface of the aquatic system. At the same time, under conditions of a lack of light, UV-r can act negatively on plants that are located close to the surface of the water, and at the same time positively as an additional source of energy - on benthic plants.

Keywords: ultraviolet irradiation; aquatic plants; exposure; changes; low light levels

\section{Вплив ультрафіолетового випромінювання на водну рослинність в умовах низьких рівнів освітлення}

\author{
О. О. Шугуров, Г. М. Олійник
}

Дніпровський національний університет імені Олеся Гончара, Дніпро, Україна

У дослідах на водній рослинності - роголисник занурений (Ceratophyllum demersum), папороть тайська (Microsorium pteropus), куляста кладофора (Aegagropila linnaei), вивчали вплив ультрафіолетового опромінення (УФ-О) за умов загальної 
недостатності освітлення. У процесі роботи вимірювали морфометричні параметри (маса, площа листя, довжина) та колір рослинності при 30-добовій безперервній експозиції 3 одночасним освітленням водних резервуарів білим світлом (2 малопотужних світлодіоди по 0,06 Вт з силою світла у 600 мкд). Як контрольний зразок був варіант тільки 3 двома білими світлодіодами, у всіх інших випадках використовували додатково 2 або 6 УФ-світлодіоди. Виявлено, що при загальній малій потужності білого освітлення додаткове УФ-О може давати різноспрямований ефект на рослинність, яка мешкає на різних рівнях водної системи. УФ-О на безкореневі рослини верхніх шарів водних систем (Ceratophyllum demersum) впливає негативно через відомі порушення фотосинтетичного апарату. Це призводило до зменшення маси рослин та площі листя, порушень життєдіяльності, розвитку процесів гниття тканин та навіть загибелі. На кореневі рослини (Microsorium pteropus) зі стрілоподібним листям додаткове УФ-О може виявити підтримку світлового балансу та певною мірою компенсувати (на 10-15\%) загальне падіння рівня розвитку (на 60-75\%). Придонна рослинність (Aegagropila sauterii), що мешкає на глибині до 5 м, здатна компенсувати недолік природного за рахунок УФ-опромінення, яке проникає в товщу води після перевипромінювання у вигляді довших хвиль, та далі використовуються, що дає загальне зростання параметрів, що вимірювали, на 5-20\%.

Ключові слова: ультрафіолетове опромінення; водні рослини; експозиція; зміни; низькі рівні освітлення

\section{Вступ}

Багатовекторний антропогенний вплив на біосферу вже призвів до цілого ряду екологічних змін: виснаження озону стратосфери, підвищення рівня ультрафіолетової радіації 3 довжиною хвилі від 10 до 400 нм. Катастрофічне зменшення стратосферного озону в Арктиці, відповідно до доповіді у Женеві навесні 2011 року (Sixteenth world meteorological congress, 2011), показує потенційну небезпеку додаткового УФ-опромінення (УФ-О) на сільськогосподарські культури. Як виявлено, різні рівні УФ-О можуть різнонаправлено впливати на урожай сільськогосподарських культур. Так, навіть незначне збільшення його інтенсивності у сонячному спектрі здатне викликати істотні зміни зростання та розвитку наземних рослин (Manin, Kozmin, 2011). Наприклад, у такої рослини, як горох (Pisum sativum L. cv Meteor) УФ-О змінювало водний баланс та газообмін при потоці потужності 0,63 Вт/м² при експозиції у 12 діб (Nogues et al., 1998). Можна відмітити, що УФ-О становить лише невелику частину сонячної радіації, що досягає поверхні Землі, однак воно являє собою важливий світловий сигнал, на який рослини можуть реагувати та розвивати специфічні фотоморфогенні реакції (Jenkins, 2009; Robson et al., 2015).

Водні рослини також здатні відчувати вплив УФ-О, особливо ті, що знаходяться на або біля іiі поверхні. Так, у дослідах на рясці малій (Lemna m.), вивчаючи вплив тривалого ультрафіолетового випромінювання на зростання та ії розмноження, а також на процеси витягання зі стічних вод важких металів (мідь) методом фіторемедіації (Olshanskaja et al., 2011), виявлено, що УФ-О, незалежно від тривалості експозиції, пригнічує зростання та розмноження цієї рослини. Хоча малі дози позитивно впливали на вилучення ними 3 водних стоків катіонів міді, але тривала дія УФ для рослини стала стресовим чинником, що давав негативний вплив (Povtareiko et al., 2017).

У наш час моніторинг рівнів та доз сонячного УФ випромінювання $\epsilon$ значною частиною глобального екологічного моніторингу, який проводиться приладами наземного та орбітального базування, але роботи, спеціально присвячені експериментальному й теоретичному вивченню УФ опромінення водних середовищ поверхневих водойм на різних глибинах, практично відсутні. У зв'язку із зазначеними обставинами метою робити стало виявлення морфологічних змін у водних рослин, які мешкають на різній глибині модельної водної системи в умовах низького рівня стандартного освітлення під впливом додаткового малопотужного УФ-О.

\section{Матеріали та методи досліджень}

У модельних лабораторних дослідах використовували такі акваріумні рослини: роголисник занурений (Ceratophyllum demersum), папороть тайська (Microsorium pteropus) та водорості - кладофору шароподібну (Aegagropila linnaei). У кожному 3 повторів дослідів (5) місткості з водою по 3 літри 3 усіх боків закривали чорним папером та розміщували по 3 рослини кожного виду. Зверху над водною поверхнею встановлювали світлодіоди: 2 білих (контрольний варіант), 2 білих + 2 УФ, 2 білих + 6 УФ.

Усі світлодіоди були малопотужними $(0,06 \mathrm{BT})$ типу FYL-3014SRC, 3 напругою живлення 3 В та силою світла у 600 мкд (для білих). УФ-світлодіоди формували хвилі 3 довжиною 380 нм (за паспортом виробника) (Shubert, 2006). Оскільки такі хвилі очі дослідника не сприймають, то оцінку їх роботи проводили за загальною потужністю стандартними вимірюваннями сили струму діодів при відомій напрузі.

На початку досліду кожну 3 рослин висушували паперовими серветками та проводили вимірювання лінійних характеристик рослин (листя, стебла, коріння), їх масу (електронними вагами 3 точністю 0,01 г) та середній діаметр водорості (для кладофори), також оцінювали загальний вигляд та (використовуючи фотоапарат) колір по умовній 10-бальній шкалі. Ці параметри вимірювали в кінці кожного досліду повтору, тривалість якого складав 30 діб.

У процесі роботи намагалися вибирати рослини та водорості близьких між собою розмірів, у кожному 3 повторів використовували інші рослини даних видів. У процесі дослідження використовували попередньо відстояну воду, температуру якої підтримували водонагрівачем на рівні $22^{\circ} \mathrm{C}$. До проведення дослідів на дно місткостей засипали відмитий пісок та додавали по 3 таблетки добрива для підживлення акваріумних рослин AQUAYER Удо Єрмолаєва (маса кожної таблетки - 0,3 г) зі складом: $\mathrm{Ca}-32,0$ г/кг, $\mathrm{Fe}-8,2$ г/кг, $\mathrm{K}-0,3$ г/кг, $\mathrm{N}-$ 16,0 г/кг, $\mathrm{P}-0,33$ г/кг, $\mathrm{Mg}-1,0$ г/кг, $\mathrm{Na}-0,2$ г/кг, $\mathrm{Mn}-$ 0,07 г/кг, Zn - 0,05 г/кг. Для статистичної обробки даних використали програму Statistica v.6.

\section{Результати та їх обговорення}

Для наших дослідів характерно те, що використані види в процесі свого життя розташовуються у водоймах на різних глибинах: кладофора завжди живе на їх дні, структура кореневої папороті тайської дає можливість листям тягнутися в напрямок поверхні, роголисник занурений існує біля самої кромки водної поверхні. Відповідно той або інший (позитивний або негативний) ефект впливу УФ-опромінення на вказані водні рослини повинен суттєво відрізнятися у зв'язку із вказаною специфікою розташування та проникнення хвиль у товщу води. Незважаючи на те що для дослідів відбирали рослинність 3 близькими параметрами, але певні морфометричні відмінності все-таки були попередньо відзначені (табл. 1).

Наприклад, у кладофори, яка часто мала еліптичну форму, вимірювали великий та малий діаметри та вираховували середне значення, яке й лягало в основу іiі специфічного цифрового рівня.

Через місяць після перебування рослинності у місткостях позитивне зростання початкових параметрів 
Таблиця 1

Середні біометричні показники досліджуваної водної акваріумної рослинності у місткостях на початку дослідження

\begin{tabular}{cccccccc}
\hline \multirow{2}{*}{\begin{tabular}{c}
\multirow{2}{*}{ п } \\
п/п
\end{tabular}} & \multirow{2}{*}{ Варіант опромінення } & \multicolumn{2}{c}{ Роголисник занурений } & \multicolumn{2}{c}{ Папороть тайська } & \multicolumn{2}{c}{ Кладофора } \\
\cline { 3 - 8 } & $\begin{array}{c}\text { довжина } \\
\text { стебла, см }\end{array}$ & \multirow{2}{*}{ маса, г } & $\begin{array}{c}\text { довжина } \\
\text { стебла, см }\end{array}$ & маса, г & $\begin{array}{c}\text { середній діаметр } \\
\text { водорості, см }\end{array}$ & маса, г \\
\hline 1 & 2 білих & $15 \pm 0,6$ & $2,42 \pm 0,63$ & $16 \pm 1,3$ & $1,24 \pm 0,11$ & $3 \pm 0,25$ & $8,75 \pm 1,3$ \\
2 & 2 білих та 2 УФ & $13 \pm 0,5$ & $2,23 \pm 0,14$ & $13,5 \pm 0,85$ & $1,099 \pm 0,08$ & $3 \pm 0,4$ & $11,39 \pm 1,9$ \\
3 & 2 білих та 6 УФ & $15 \pm 0,9$ & $2,15 \pm 0,12$ & $15 \pm 0,73$ & $1,31 \pm 0,09$ & $3 \pm 0,3$ & $12,14 \pm 2,0$ \\
\hline
\end{tabular}

було виявлене у водорості - кладофори (середня початкова маса за всіма дослідами складала 10,76 г). У контрольному експерименті (лише два білих світлодіоди) середній приріст маси водорості складав 10,3 $\pm 0,8 \%$, а вже 32 додатковими УФ-діодами - 10,9 $\pm 1,1 \%$, а 36 діодами $20 \pm 3,16 \%$.

Практично в усіх дослідах (контрольних та експериментальних) колір «кулі» водорості був насичений зелений, діаметр їі підвищувався відповідно від 7 до $15 \%$ $(3,2 \pm 0,06$ см), маса максимально зростала на 15-20\% відносно контрольного варіанта дослідів. Наведені дані свідчили, що експериментальні умови освітлення, в яких проводилися досліди, є прийнятними для розвитку лише при наявності додаткового (навіть і УФ) опромінення.

Відповідно до зростання лінійних параметрів рослин змінювалися і їх масові характеристики (рис.1).

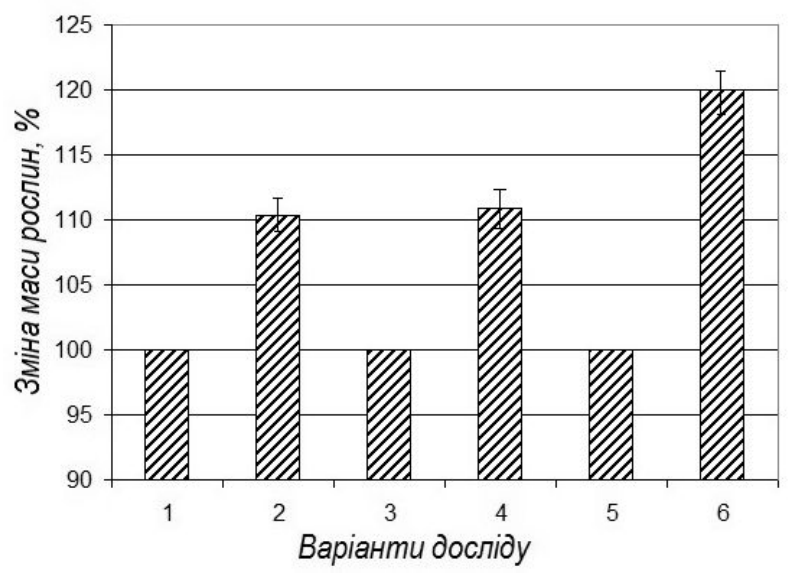

Рис. 1. Середні зміни маси кладофори за один місяць досліду: 1, 2 - при освітленні 2 білими світлодіодами (контроль), 3, 4-2 білих та 2 УФ, 5, 6-2 білих та 6 УФ. 1, 3, 5 - на початку досліду, 2, 4, 6 - наприкінці. Середня початкова маса рослин - 10,76 г, середня кінцева за всіма варіантами дослідів - 12,28 г. Наведено середньоквадратичні відхилення.

Особливо цей процес був відмічений для варіанта 3 6 додатковими джерелами УФ-О (6 на рис. 1), але також виявлений і для малого додаткового (відносно контролю) освітлення (+2 УФ-діоди).

Життєдіяльність папороті тайської виявили дещо іншу специфіку. Ця акваріумна рослина має значну кореневу систему, а iï подовжене листя росте вгору - до поверхні води. Наші вимірювання свідчать про факт, що лише одного білого світла (контроль) вказаної малої потужності для них було все ж недостатньо для їх нормального розвитку, що приводило вже через місяць такого існування до зменшення маси рослин до 30 \% від початкового рівня (стовпчик 2 на рис. 2). Також спостерігалося пожовтіння листя рослин та навіть гниття стебла листя, що й приводило до зменшення сумарної маси рослин даного виду.

Додаткове освітлення місткості з рослинами у вигляді 2 УФ світлодіодів трохи компенсувало вказану недостачу, внаслідок чого зменшення маси рослини доходило до $40 \%$ від початкового рівня. У дослідах 3 шістьма додатковими світлодіодами УФ-О декілька компенсувало загальну недостачу освітлення, яке дуже потрібне для листя папороті. Як наслідок - пригноблення лінійних параметрів рослини складало менш як 50 \%. Тобто УФ хвилі хоча й не компенсували необхідного рівня освітлення листів рослини у товщі води, але явно використовувалося ними для своїх потреб на фоні низьких рівнів освітлення акваріумів.

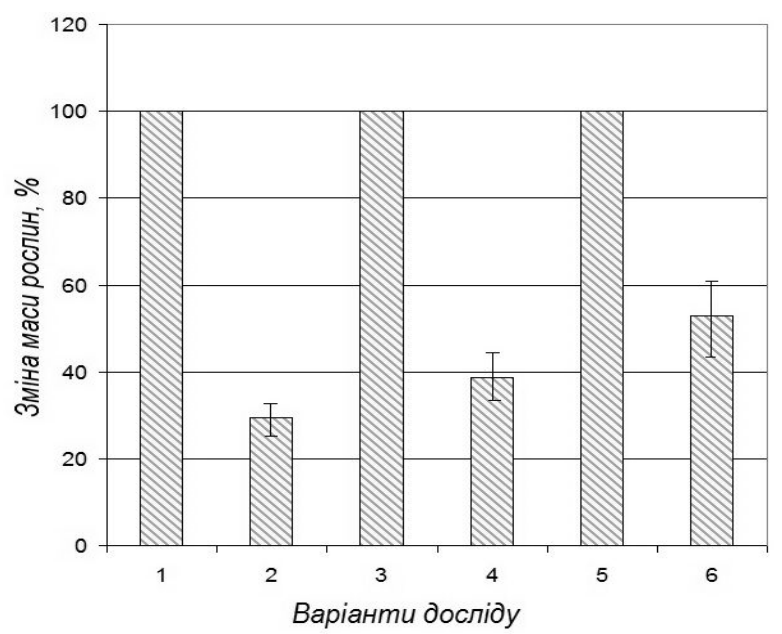

Рис. 2. Середні зміни маси папороті тайської в місячному досліді: 1, 2 - при освітленні 2 білими світлодіодами, 3, 4 2 білих та 2 УФ, 5, 6 - 2 білих та 6 УФ діодів. 1, 3, 5 - на початку досліду, 2, 4, 6 - наприкінці. Середня початкова маса рослин - 0,94 г, середня кінцева за всіма варіантами дослідів - 0,49 г. Наведено середньоквадратичні відхилення.

УФ-О акваріумних рослин, які використовувалися в дослідах та існують близько поверхні водойми (роголисник занурений), проявило суттєву негативну дію (рис. 3). Це проявляється суттєвим (до 93 \%) зменшенням маси рослин (аж до їх загибелі) при опроміненні УФхвилями 36 додаткових світлодіодів (стовпчик 6 на рис. 3), та до $90 \%$ - при опроміненні двома додатковими УФдіодами (стовпчик 4).

При оцінці результатів дослідів треба врахувати сучасні дані про вплив УФ-О на рослинний світ. Ультрафіолетову частину випромінювання 3 сонця зараз умовно ділять на три піддіапазони по довжині хвиль: УФА $(\lambda=315-400$ нм), УФ-В ( $\lambda=280-315$ нм) та УФ-С $(\lambda<280$ нм $)$. Хвилі діапазону УФ-В мають більшу біологічну активність, ніж УФ-А, а УФ-С - уже повністю поглинаються атмосферою. В умовах антропогенного забруднення атмосфери та наявності озонових дірок вплив УФ-О постійно підвищується: за даними, від 30 до $60 \%$ потоку хвиль УФ-А та УФ-В, які падає на водну поверхню, здатні проникнути до глибини у 5 м (Makarov, 1996).

У деяких поверхневих рослин (горох) УФ-О тривале опромінення при потужності 0,63 Вт/м ${ }^{2}$ призводить до зменшення адаксіальної провідності провідників на 65 \%, збільшивши обмеження поглинання $\mathrm{CO}_{2}$ на 10-15\%, та виявляє втрати фотосинтетичної активності листя (Nogues et al., 1998). Зростання УФ-О призвело до значного зменшення площі листя та загальної біомаси рослин, гальмування епідермального розширення клітин відкритої 
поверхні листя. Серед реакцій рослин зазвичай описуються зміни в морфології, фізіології та виробництві вторинних метаболітів. УФ-О-специфічний фоторецептор RESISTANT LOCUS (UVR8) регулює ці фотоморфогенні реакції, контролюючи експресію генів, які беруть участь в інгібуванні подовження гіпокотилю, репарації ДНК, антиоксидантному захисті та виробництві фенольних сполук, які можуть діяти як молекули, що захищають від УФ-променів (Rizzini et al., 2011). Для того щоб зменшити окислювальне пошкодження та проникнення ультрафіолетового світла до шарів фотосинтезувальних клітин, рослини можуть накопичувати флавоноїди та фенілпропаноїди в епідермісі листя, а також у частоколі та губчастій тканині мезофілу (Agati et al., 2013).

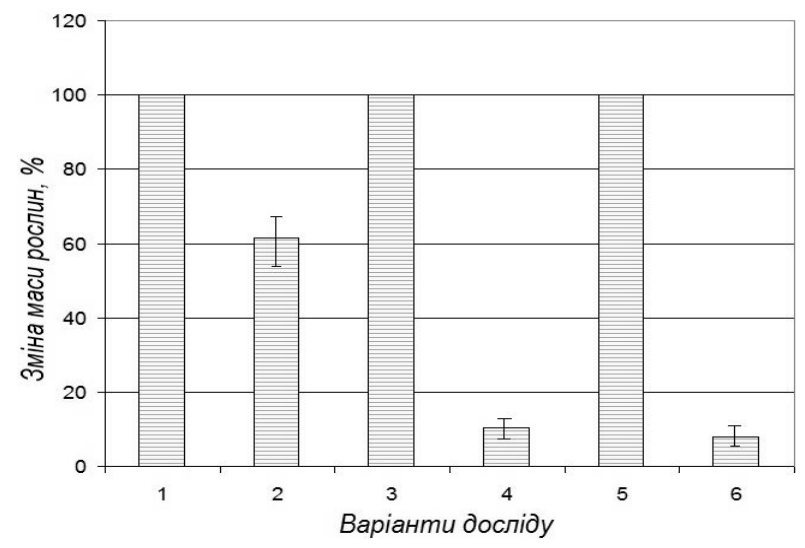

Рис. 3. Середні зміни маси роголисника зануреного за один місяць досліду: 1,2 - при освітленні 2 білими

світлодіодами, 3,4 - 2 білих та 2 УФ, 5, 6 - 2 білих та 6 УФ. $1,3,5$ - на початку досліду, 2, 4, 6 - наприкінці. Середня початкова маса рослин $-2,27$ г, середня кінцева за всіма варіантами дослідів - 0,57 г. Наведено середньоквадратичні відхилення.

Рослини можуть реагувати на одночасні або послідовні зміни абіотичних умов, модулюючи свою фізіологію, а отже, i хімію. Адаптаційні реакції рослин на зовнішні зміни умов вирощування можуть мати глибокий вплив на їх реакцію на біотичні стреси (Gutbrodt et al., 2011; Nguyen et al., 2016). Дворічні експерименти 3 вивчення впливу підвищених доз УФ-радіації ( $\lambda=308$ нм) на рослини показали, що остання дає виражений негативний вплив на фотосинтетичний апарат хвої ялини сибірської (Picea obovata Ledeb.) при вираженому кумулятивному ефекті (Zuev et al., 2017). При цьому водний баланс хвої рослин опроміненої та контрольної груп відповідав сезонним нормам, але абіотичні фактори здатні значно модулювати УФ-впливи, пов'язані зі специфікою хімізму рослин (Escobar-Bravo et al., 2017).

С дані, що УФ-О гальмує функціональну активність планктонних водоростей шляхом впливу на рух клітин, зменшення їх зростання, фотосинтез, фіксацію азоту) (Masyk et al., 2007), проте вони стосуються в основному морських видів. За приблизними оцінками, при скороченні озонового шару на $25 \%$ фотосинтез фітопланктону зменшиться приблизно на 35 \% (Rudneva et al., 2010).

Слід урахувати, що будь-які електромагнітні хвилі в рідких середовищах (що мають розчинені речовини), поширюючись крізь їх речовину, стають причиною додаткового коливання електронів в іi атомах. Такі електрони, повертаючись із високоенергетичного стану до низькоенергетичного, викидають вторинні електромагнітні хвилі з меншою енергією (ККД будь-якої термодинамічної дії менше як 100 \%). Іншими словами, перевипромінювання в речовині хвилі стають більш «довгими» і менш енергетичними (Voitov et al., 1970; Titik et al., 2019). Так, на математичних моделях показано (Krasovski et al., 2020), що на глибині 10 м від поверхні спектральна щільність енергетичної освітленості в діапазоні 280-450 нм зменшується в 10 (або навіть більше) разів.

Відповідно, розглядаючи дані дослідів на водних рослинах, що живуть на різних глибинах 3 використанням УФ-світлодіодів для додаткового опромінення при низькому загальному освітленні рослин у водній системі, можна відмітити наступне. Таким рослинам, як тайська папороть, наявного білого світла (при освітленні акваріумів 2 білими світлодіодами) було мало для їх нормального розвитку (рис. 2). Так, для папороті додаткове освітлення у вигляді УФ, яке в міру проникнення у воду переопромінюється у вигляді менш високочастотних хвиль, дає невеличку енергетичну компенсацію, що призвело до зменшення маси лише на $60 \%$ (2 додаткових УФ-джерела) та $47 \%$ - при збільшенні кількості робочих УФ-світлодіодів до 6 при 2 білих світлодіодах, які спромоглися утримати рослини лише на рівні $30 \%$ від стартового значення (падіння - 70 \%). В усіх випадках колір листя з зеленого змінювався на жовто-зелене 3 частковим зменшенням листової поверхні та навіть кількості листя, коріння було майже незмінним по масі та довжині.

Кладофора, яка живе на придонних горизонтах, від самого початку більш пристосована до малого сонячного освітлення. Тому навіть при малому початковому освітленні вона показала зростання маси та розмірів на 10,8 \% (рис.1), додавання опромінення від 2 УФ-джерел виявили підвищення на $12,5 \%$, а додаткове підключення 6 світлодіодів зростання сягало 20,2 \% від початкового рівня. Практично кожна водорость мала свій стандартний колір та щільність структури, що говорило про прийнятні умови життя.

Роголисник - це приповерхнева водна рослина, яка активно вбирає в себе сонячне світло, яке досить легко проходить крізь незначну товщу води. Зменшення загального рівня освітлення до низького (2 діоди по 600 мкд) веде до гальмування нормальної фотосинтетичної діяльності на 38,6 \% (рис. 3). При цьому наявність додаткових джерел опромінення у вигляді УФ-діодів не тільки не компенсує таку недостачу, але ще й посилює гноблення нормальної життєдіяльності на 86 \% (з двома джерелами) та 93 \% (3 шістьома). При цьому було відмічено зміну зеленого кольору рослин на жовто-коричневу, тканини рослин цього виду були м'якими та слизькими. Як можна бачити, результати показали, що для роголисника нарощення кількості УФ-джерел приводило до поглиблення загального гноблення рослин даного виду (аж до їх загибелі у 63 \% випадків).

Оцінюючи дані наших досліджень, треба підкреслити, що як контроль була вибрана модель 3 невеликим освітленням, оскільки рослини без світла взагалі не зможуть зростати. Дані свідчать, що додаткове освітлення у вигляді УФ-О може різнопланово впливати на водну рослинність, особливо в умовах специфіки їх розташування (горизонтальне або вертикальне) у товщі води та глибині надходження. Перший фактор впливає на ступінь дії світлових променів на листя та стебла рослин, 3 останнім параметром пов'язана специфіка проникнення хвиль у глибину води та формування зміни довжини хвиль у процесі розсіювання на розчинених елементах.

Відповідно для вибраної для дослідів водної рослинності підхід впливу та подальшого прогнозу $\epsilon$ різнобічний. Так, роголисник занурений (Ceratophyllum demersum) не лише знаходиться у відносно верхніх шарах водних систем, але (вірогідно) орієнтується саме на специфічну довжину хвиль, що падають. При цьому додаткове УФ-опромінення, легко проникаючи у такі шари води на фоні малої освітленості, гнобить фотосинтетичні процеси, що відмічено раніше. Такі зміни неминуче ведуть до зменшення маси таких рослин та їх загибелі.

Для рослинності, яка присутня у донних ділянках водних систем (кладофора шароподібна - Aegagropila linnaei), вказане сумісне до білого світла УФ-випромінення після свого розсіювання та перевипромінювання діє на неї лише як додаткове освітлення прийнятного діапазону. 
Оскільки донні рослини звичні до нестачі світла, кожна його добавка веде до зростання маси та розміру водорості.

Папороть тайська (Microsorium pteropus) може варіювати своїми елементами (листя, коріння) у декількох шарах води та донного грунту, орієнтуючись у першу чергу на належне освітлення листя. Останні, прагнучи вгору до світла, якого від самого початку було недостатньо, на фоні загального падіння рівня розвитку, отримували в рівній (2 до 2 світлодіодів) або переважній (2+6) дозі опромінення хвилями УФ-діапазону та певну підтримку для своєї фотосинтетичної діяльності

\section{Висновки}

Таким чином, 3 проведених дослідів можна зробити такі висновки:

- При малому загальному рівні освітлення на рослини, що мешкають у верхніх шарах водних систем (Ceratophyllum demersum), УФ-опромінення впливає негативно через відомі порушення фотосинтетичного апарату, що протягом місяця веде до дуже суттєвого зменшення маси рослин та площі їх листя (на 80-90\%), порушень у життєдіяльності, розвитку процесів гниття тканин та подальшої загибелі.

- Водні рослини, що вкорінюються та мають стрілоподібне листя (наприклад, Microsorium pteropus), які направлені вверх до поверхні, на фоні слабкого загального освітлення проявляють суттєве гноблення зростання (до 75 \% за місяць), використовуючи додаткове УФ-опромінення, після ïx розсіювання у воді можуть певною мірою підтримувати свій світловий баланс та компенсувати наявне затемнення (на 25-30\%).

Придонна рослинність (на прикладі водорості кладофори шароподібної - Aegagropila linnaei), що мешкає на невеликій глибині (до 5 м), здатна компенсувати нестачу природного освітлення додатковим УФ-опроміненням, яке після проникнення у товщу води перевипромінюється на значну глибину у вигляді більш довгих хвиль, які вже використовуються такою рослинністю при загальному ïi зростанні (на 5-10\%).

- Додаткове ультрафіолетове опромінення на фоні низького природного освітлення може діяти на водні рослини двояко - негативно впливати на тих 3 них, що живуть у верхніх шарах водойми, та позитивно - для рослин, що існують у придонних шарах водойм.

\section{References}

Agati, G., Brunetti, C., Di Ferdinando, M. (2013). Functional roles of flavonoids in photoprotection: new evidence, lessons from the past. Plant Physiol. Biochem., 72, 35-45.

Escobar-Bravo, R., Klinkhamer, P. G. L., Leiss, K. A. (2017). Interactive effects of UV-B light with abiotic factors on plant growth and chemistry, and their consequences for defense against arthropod herbivores. Front. Plant Sci., Mar 2:8:278.

Gutbrodt, B., Mody, K., Dorn, S. (2011). Drought changes plant chemistry and causes contrasting responses in lepidopteran herbivores. Oikos, 120, 1732-1740.

Jenkins, G.I. (2009). Signal transduction in responses to UV-B radiation. Annu. Rev. Plant Biol., 60, 407-431.

Krasovski, A. N., Turishev, L. N., Svetashev, A. G., Demin, V. S., Dorozko, N. V., Ermolovich, Ju. G. (2020). Algoritmi i programnoje obespechenie dla chislennogo modelirovania doz obluchenia vodnich sloev pridonnih vodoemov solnechnim izlucheniem razlichnih spectralnich diapazonov [Algorithms and software for numerical modeling of doses of irradiation of water layers of natural reservoirs with solar radiation of various spectral ranges]. V sb. docl. mejdunarod. nauch. konf. pam. Ju. B. Vinogradova «4-Vinogradov. chtenia. Hydrol. ot poznania $k$ mirovozreniju». S-Pb.:S-Pb. gos. un-y., 106-110 (in Russian).
Makarov, M. V. (1996). Vlijanie ultrafioleta na rost massovich vidov vodoroslej Barentseva morja [Influence of ultraviolet radiation on the growth of mass species of algae in the Barents Sea]. Ecol.-physiol. issl. vodoroctej i ih znachenie dla otsenki sostojania prirod. vod.- Jaroslavl: Izd. RAN, 150-152 (in Russian).

Manin, K. V., Kozmin, G. V. (2011). Metodicheskie aspecti otsenki agroecologitheskih posledstvij istoschenia ozona stratospheri [Methodological aspects of assessing the agroecological consequences of stratospheric ozone depletion]. Vestnic Vseros. Acad. Estest. nauk, 2 (2), 48-52 (in Russian).

Masyk, N. P., Posudin, Ju. I., Lilitskaya, G. G. (2007). Fotodvishenie kletok Dunaliella Teod. (Dunaliellales, Chlorophyceae, Viridiplantae) [Photomotion of Dunaliella Teod cells (Dunaliellales, Chlorophyceae, Viridiplantae)]. Kyiv, 265 p. (in Russian).

Nguyen, D., D'Agostino, N., Tytgat, T. O. G., Sun, P., Lortzing, T., Visser, E. J. W., Cristescu, S. M., Steppuhn, A., Mariani, C., van Dam, N. M., Rieu I. (2016). Drought and flooding have distinct effects on herbivore-induced responses and resistance in Solanum dulcamara. Plant Cell. Environ., 39, 1485-1499.

Nogues, S., Allen, D. M., Morison, J. I. L., Bakerm, N. R. (1998). Ultraviolet-B radiation effects on water relations, leaf devekopment, and photosynthesis in droughted pea plants. Plant Physiol., 117 (1), 173-181.

Olshanskaja, L. N., Sobgajda, N. A., Stojanov, A. V. (2011). Izuchenie vlijanija ultrafioletovogo izluchenia na processi razmnojenia raski maloj (lemna M.) i izvlechenie medi iz stochnich vod [Study of the influence of ultraviolet radiation on the reproduction of duckweed (lemna M.) and the extraction of copper from wastewater]. Vestnic HNADY, 52, 87-90 (in Russian).

Povtareiko, A. A., Kudziev, G. A., Shurgaeva, E. V., Mishenina, I. V. (2017). Vlijanie luchevogo izluchenia na vodu $\mathrm{i}$ rost rastenij [Effect of radiation on water and plant growth]. Mat. nauk.-tech. konf. obuch. i molod. ychenich SKGMI (GTU) "NTK-2017". Vladikavkaz:Severo-Kavkaz. gorno-metall. inst., 175-177 (in Russian).

Rizzini, L. Favory, J.-J., Cloix, C., Faggionato, D., O'Hara, A., Kaiserli, E., Baumeister, R., Schäfer, E., Nagy, F., Jenkins, G. I., Ulm, R. (2011)/ Perception of UV-B by the Arabidopsis UVR8 protein. Science, 332, 103-106.

Robson, T., Klem, K., Urban, O., Jansen, M. A. (2015). Reinterpreting plant morphological responses to UV-B radiation. Plant Cell Environ, 38, 856-866.

Rudneva, I. I., Shaida, V. G. Vlijanie ultrafioletovogo izluchenia na morskie bioresursi: analiz riska dla ecosystemi i bioti [Impact of ultraviolet radiation on marine bioresources: risk analysis for ecosystem and biota] Ribne hozajstvo, 5, 68-70 (in Russian).

Sixteenth world meteorological congress: abridged final report with resolutions. (2011). World Meteorological Congress 16th session (16 May-3 June 2011; Geneva, Switzerland). Part I - Abridged final report with resolutions, Part II Progress Report. Pub.: WMO. ISBN: 978-92-63-11077-0.

Shubert F. (2006). Light-emitting diodes (Second ed.), Pub. USA Cambr. Univ. Press, New York. 422 p.

Titik, D. L., Busev, S. A., Visotsky, V. V., Revina, A. A., Suvorov, J. V., Kuzmin, V. I., Gadzaov A. F. (2019). Effect rassejania ultrafioletovogo izluchenia deionizirovannoj vodi The scattering effect of ultraviolet radiation by deionized water]. J. Fiz. chimii, 93 (12), 1865-1869 (in Russian).

Voitov, V. I., Ochakovski, Ju. E., Kopelevich O. V. (1970). Svet $\mathrm{v}$ more [Light in the sea]. Moscow, Nauka (in Russian).

Zuev, V. V., Zueva, N. E., Korotkova, E. M., Bender, O. G. (2017). Issledovanie otklika fotosintetacheskogo apparata eli sibirskoj (picea obovata ledeb.) na dvochletnee vozdejstvie povishenih doz UV-radiatsii [Investigation of the response of the photosynthetic apparatus of Siberian spruce (picea obovata ledeb.) on two-year exposure to increased doses of UV radiation]. Optica atmospheri $\mathrm{i}$ oceana, 30 (9), 799-805 (in Russian). 